\title{
DASAR WAJIB MEMATUHI UNDANG-UNDANG PERKAWINAN (UUP): STUDI PEMIKIRAN MUHAMMAD ‘ABDUH
}

\author{
Khoiruddin Nasution* \\ Universitas Islam Negeri (UIN) Sunan Kalijaga Yogyakarta \\ Email: knasut@gmail.com
}

\begin{abstract}
One reason why the Marriage Law (UUP) is not obeyed is related to the status of compliance. According to the majority of Muslims, the status of obeying the contents of the UUP is related to and is a matter of the State, not related to the legality of religion, not related to the validity of marriage. Instead Muhammad 'Abduh is a thinker who believes that obeying the UUP is part of an obedient obligation to the government (uli al-amr), the same status as being obliged to obey Allah and His messengers, as required in al-Nisa' (4): 59 and 83. Thus, obeying the UUP is part of implementing compliance with the government. So obeying UUP is an obligation for every Muslim. Likewise, the UUP as a decision of people's representatives is an expression of the agreement of all the people. The people are represented by people who are elected by the people (people's representatives), because to gather all the people, at present, is impossible. So the decision of the people's representatives is positioned as the decision of all the people. The decision of the people's representatives for now becomes ijmâ ', the third source of Islamic law after the Qur'an and the Sunnah of the Prophet Muhammad SAW. The final basis stipulates the obligation to obey the Marriage Law, compared to fiqh, fatwa, interpretation, and jurisprudence, as a product of Islamic legal thinking, the UUP occupies the most authoritative and comprehensive position, because the UUP is the result of the minds of many scholars and expertise. This paper tries to explain the concept of 'Abduh.
\end{abstract}

Keywords: Marriage Law, Jurisprudence, Fatwa, Law.

\begin{abstract}
Abstrak
Salah satu sebab mengapa Undang-Undang Perkawinan (UUP) tidak dipatuhi adalah berkaitan dengan status mematuhinya. Menurut mayoritas muslim, status mematuhi isi UUP berkaitan dengan dan merupakan urusan Negara, bukan berkaitan dengan legalitas agama, bukan berkaitan dengan absah atau tidaknya perkawinan. Sebaliknya Muhammad 'Abduh adalah pemikir yang berpendapat bahwa mematuhi UUP merupakan bagian dari kewajiban patuh kepada pemerintah (uli al-amr), sama statusnya dengan wajib patuh kepada Allah dan rasulNya, sebagaimana diwajibkan dalam al-Nisa' (4): 59 dan 83. Dengan demikian, mematuhi UUP merupakan bagian dari pelaksanaan patuh kepada pemerintah. Maka mematuhi UUP merupakan kewajiban bagi setiap muslim. Demikian juga UUP sebagai keputusan wakil-wakil rakyat adalah wujud kesepakatan seluruh rakyat. Rakyat diwakili oleh orang-orang yang dipilih rakyat (wakil rakyat), sebab untuk mengumpulkan seluruh rakyat, saat ini, adalah sesuatu yang tidak mungkin. Jadi keputusan wakil-wakil rakyat ini
\end{abstract}

* Dosen Fakultas Syariah dan Hukum Universitas Islam Negeri (UIN) Sunan Kalijaga Yogyakarta; Pengajar Fakultas Hukum UII, Pengajar Program MSI (S2)-UII; Pengajar S3 Pascasarjana UIN Raden Intan Lampung, Ketua Asosiasi Dosen Hukum Keluarga Islam (ADKHI) Indonesia. 
diposisikan sebagai keputusan seluruh rakyat. Keputusan perwakilan rakyat untuk saat ini menjadi ijmấ, sumber ketiga hukum Islam setelah al-Qur'an dan sunnah rasul Muhammad SAW. Dasar terakhir menetapkan kewajiban patuh pada Undang-Undang Perkawinan, dibandingkan dengan fikih, fatwa, tafsir, dan yurisprudensi, sebagai produk pemikiran hukum Islam, UUP menempati posisi paling otoritatif dan konprehensif, sebab UUP merupakan hasil pimikiran banyak ahli dari berbagai keilmuan dan keahlian. Tulisan ini mencoba menjelaskan konsep 'Abduh tersebut.

Kata Kunci: Undang-Undang Perkawinan, Yurisprudensi, Fatwa, Hukum.

\section{Pendahuluan}

Mematuhi/menaati Undang-Undang Perkawinan (UUP) bagi 'Abduh adalah sama dengan mematuhi/menaati al-Qur'an dan Sunah rasul Muhammad SAW. Sebab UUP adalah ketetapan, keputusan atau kesepakatan wakil rakyat (Dewan Perwakilan Rakyat [DPR], legislatif) bersama pemerintah (eksekutif). Mematuhi UU yang ditetapkan oleh wakil rakyat dan pemerintah tersebut adalah bentuk kepatuhan kepada pemerintah (uli al-amr). Kewajiban patuh kepada pemerintah dalam bentuk mematuhi hukum/undang-undang merupakan realisasi perintah patuh kepada Allah, patuh kepada rasul dan patuh kepada pemerintah (uli al-amr), sebagaimana diperintahkan dalam al-Nisâ' (4): 59 dan 83. Keputusan DPR sebagai wakil rakyat merupakan realisasi kesepakatan seluruh rakyat. Rakyat secara keseluruhan diwakili oleh anggota parlemen (DPR, representative), karena untuk mengumpulkan seluruh rakyat, untuk saat ini, adalah sesuatu yang tidak mungkin. Sebagai solusinya, sistem perwakilan merupakan cara yang bisa ditempuh. Jadi keputusan wakil-wakil rakyat ini diposisikan sebagai keputusan seluruh rakyat. Konsekuensinya, keputusan ini wajib dipatuhi. Persetujuan perwakilan rakyat untuk saat ini juga menjadi ijmâ', sumber ketiga hukum Islam setelah al-Qur'an dan sunnah rasul Muh\}ammad saw. Sebagai tambahan, dibandingkan dengan fikih, fatwa, tafsir, dan yurisprudensi, sebagai produk pemikiran hukum Islam, UUP menempati posisi paling otoritatif dan konprehensif, sebab UUP merupakan hasil pimikiran banyak ahli dari berbagai keilmuan dan keahlian.

Tulisan ini mencoba menjelaskan bagaimana konsep yang diajukan Muhammad 'Abduh, dan seberapa relevan teori ini cocok untuk mematuhi hukum yang ditetapkan di Indonesia, sebagai bentuk kepatuhan kepada pemerintah (uli al-amr), seperti yang disebutkan dalam al-Qur'an surah al-Nisa' (4): 59 dan 83, dan sebagai manifestasi ketaatan kepada ijmấ. Ruang lingkup dan sistematis pembahasan tulisan ini adalah penjelasan tentang proses pembuatan undang-undang dalam sistem konstitusi Indonesia, setelah latar belakang. Kemudian dijelaskan konsep ijma' Muhammad 'Abduh. Setelah itu diperlihatkan otoritas undang-undang Indonesia ketika berkorelasi dengan konsep ijmât Muhammad 'Abduh. Akhirnya tulisan ditutup dengan catatan kesimpulan.

\section{Proses Pembuatan UU dalam Konstitusi Indonesia}


Mengenai proses pembentukan UU dalam Konstitusi Indonesia, lebih khusus untuk melihat kewenangan UU dapat diukur dengan mengacu pada Undang-Undang Nomor 12 Tahun 2011 tentang Pembentukan Peraturan Perundang-Undangan. ${ }^{1}$ Dari 13 bab dan 104 pasal yang terkandung dalam undang-undang ini, ada 6 (enam) bab yang relevan dengan otoritas UU, yaitu Bab IV: Perencanaan, Bab V: Penyusunan Peraturan Perundang-Undangan, Bab VII: Pembahasan dan Penetapan Rancangan Undang-Undang, Bab IX: Pengundangan, Bab X: Penyebarluasan, Bab XI: Partisipasi Masyarakat. ${ }^{2}$

Berdasarkan pada 6 (enam) bab tersebut dapat dicatat sembilan (9) poin. Pertama, bahwa pembuatan Peraturan Perundang-undangan mencakup lima tahapan, yakni; 1. perencanaan, 2. penyusunan, 3. pembahasan, 4. pengesahan atau penetapan, dan 5. pengundangan, sebagaimana disebutkan dalam pasal 1 ayat (1) UU ini. Masing-masing tahap tentu melibatkan banyak orang. ${ }^{3}$

Kedua, bahwa undang-undang adalah produk legislative dan eksekutif melalui prosedur tertentu, sebagaimana disebut dalam pasal 1 ayat (2). ${ }^{4}$ Bahwa UU dibentuk oleh Dewan Perwakilan Rakyat dengan persetujuan bersama Presiden, sebagaimana disebut dalam pasal 1 ayat (3). ${ }^{5}$

Ketiga, bahwa perencanaan peraturan perundang-undangan dimulai dari prolegnas yang disusun secara terencana, terpadu, dan sistematis, dalam rangka mewujudkan system hukum nasional, yang didasarkan atas aspirasi dan kebutuhan hukum masyarakat. Poin ini dapat disimpulkan dari pasal 1 ayat (9). ${ }^{6}$ Pasal 17,7 dan Pasal 18. ${ }^{8}$

1 Sebelumnya dipakai Undang-Undang No. 10 tahun 2004 tentang Pembentukan Peraturan Perundang-undangan.

2 Undang-Undang No. 12 tahun 2011 tentang Pembentukan Peraturan PerundangUndangan.

3 Dalam pasal 1 ayat (1) disebutkan," Pembentukan Peraturan Perundang-undangan adalah pembuatan Peraturan Perundang-undangan yang mencakup tahapan perencanaan, penyusunan, pembahasan, pengesahan atau penetapan, dan pengundangan".

${ }^{4}$ Dalam pasal 1 ayat (2) UU No. 12 tahun 2011 tentang Pembentukan Perundang Undangan, disebutkan, Peraturan Perundang-Undangan adalah peraturan tertulis yang memuat norma hukum yang mengikat secara umum dan dibentuk atau ditetapkan oleh lembaga negara atau pejabat yang berwenang melalui prosedur yang ditetapkan dalam Peraturan Perundangundangan".

5 pasal 1 ayat (3), "Undang-Undang adalah Peraturan Perundang-undangan yang dibentuk oleh Dewan Perwakilan Rakyat dengan persetujuan bersama Presiden".

${ }^{6}$ pasal 1 ayat (9) "Program Legislasi Nasional yang selanjutnya disebut Prolegnas adalah instrumen perencanaan program pembentukan Undang-Undang yang disusun secara terencana, terpadu, dan sistematis".

7 Pasal 17, “Prolegnas sebagaimana dimaksud dalam Pasal 16 merupakan skala prioritas program pembentukan Undang-Undang dalam rangka mewujudkan system hukum nasional".

8 Pasal 18, "Dalam penyusunan Prolegnas sebagaimana dimaksud dalam Pasal 16, penyusunan daftar Rancangan Undang- Undang didasarkan atas: a. perintah Undang-Undang Dasar Negara Republik Indonesia Tahun 1945; b. perintah Ketetapan Majelis Permusyawaratan Rakyat; c. perintah Undang-Undang lainnya; d. sistem perencanaan pembangunan nasional; e. rencana pembangunan jangka panjang nasional; f. rencana pembangunan jangka menengah; g. 
Keempat, masih perencanaan, bahwa kelahiran peraturan perundangundangan merupakan hasil telaah, yang disebut naskah akademi, sebagaimana dalam pasal 1 ayat (11). ${ }^{9}$

Kelima, dalam kaitan dengan proses penyusunan undang-undang, langkah kedua, disebutkan dalam Bab V: Penyusunan Peraturan Perundangundangan, Bagian Kesatu, Penyusunan Undang-Undang, pasal 43 sd 51. Dalam bahasan ini ada 3 pasal yang relevan dengan bahasan ini, yakni pasal 43, 44 dan 50. Inti pasal 43, bahwa Rancangan Undang-Undang dapat berasal dari DPR atau Presiden. Bahwa Rancangan Undang-Undang harus disertai Naskah Akademik dan keterangan yang memuat pokok pikiran dan materi muatan yang diatur. Sementara inti pasal 44, bahwa Naskah Akademik merupakan bagian tidak terpisahkan dari Undang-Undang. Pasal 50, DPR membahas Rancangan Undang-Undang dalam jangka waktu paling lama 60 (enam puluh) hari terhitung sejak surat Presiden diterima.

Keenam, tentang Pembahasan undang-undang, langkah ke-3, Bab VII: Pembahasan dan Pengesahan Rancangan Undang-Undang, Bagian Kesatu Pembahasan Rancangan Undang-Undang, Pasal 67. Bahwa pembahasan rancangan undang-undang dilakukan dalam dua tingkat pembicaraan, yakni: a. pembicaraan tingkat I dalam rapat komisi, rapat gabungan komisi, rapat Badan Legislasi, rapat Badan Anggaran, atau rapat Panitia Khusus; dan b. pembicaraan tingkat II dalam rapat paripurna.

Ketujuh, kaitan dengan pengesahan undang-undang, langkah ke-4, Bagian Kedua Pengesahan Rancangan Undang-Undang, Pasal 72. Inti pasal ini bahwa rancangan undang-undang yang telah disetujui DPR disampaikan pimpinan DPR untuk disahkan presiden. ${ }^{10}$

Kedelapan, terkait penyebarluasan undang-undang, Bab X: Penyebarluasan, Bagian Kesatu: Penyebarluasan Prolegnas, Rancangan UndangUndang, dan Undang-Undang, Pasal 88. Bahwa maksud penyebarluasan Prolegnas, Rancangan Undang-Undang, dan Undang-Undang adalah untuk

rencana kerja pemerintah dan rencana strategis DPR; dan h. aspirasi dan kebutuhan hokum masyarakat".

${ }^{9}$ pasal 1 ayat (11) “Naskah Akademik adalah naskah hasil penelitian atau pengkajian hukum dan hasil penelitian lainnya terhadap suatu masalah tertentu yang dapat dipertanggungjawabkan secara ilmiah mengenai pengaturan masalah tersebut dalam suatu Rancangan Undang-Undang, Rancangan Peraturan Daerah Provinsi, atau Rancangan Peraturan Daerah Kabupaten/Kota sebagai solusi terhadap permasalahan dan kebutuhan hukum masyarakat".

10 Pasal 72 (1) Rancangan Undang-Undang yang telah disetujui bersama oleh DPR dan Presiden disampaikan oleh Pimpinan DPR kepada Presiden untuk disahkan menjadi UndangUndang. (2) Penyampaian Rancangan Undang-Undang sebagaimana dimaksud pada ayat (1) dilakukan dalam jangka waktu paling lama 7 (tujuh) hari terhitung sejak tanggal persetujuan bersama. 
memberikan informasi dan/atau memperoleh masukan masyarakat serta para pemangku kepentingan. ${ }^{11}$

Kesembilan, tentang partisipasi masyaakat, dalam Bab XI: Partisipasi Masyarakat, Pasal 96 ayat (1). Bahwa masyarakat berhak memberikan masukan secara lisan dan/atau tertulis dalam Pembentukan Peraturan Perundangundangan, dapat dilakukan melalui: a. rapat dengar pendapat umum; b. kunjungan kerja; c. sosialisasi; dan/atau d. seminar, lokakarya, dan/atau diskusi, dan dapat dilakukan oleh orang perseorangan atau kelompok orang yang mempunyai kepentingan atas substansi Rancangan Peraturan Perundangundangan. Untuk memudahkan masyarakat dalam memberikan masukan, setiap Rancangan Peraturan Perundang-undangan harus dapat diakses dengan mudah oleh masyarakat. ${ }^{12}$

Dari deskripsi proses lahirnya undang-undang dalam konstitusi Indonesia, mulai dari perencanaan sampai dengan pengesahan, dapat disimpulkan betapa banyak orang yang terlibat dalam proses lahirnya. Pengelompokan orang-orang yang terlibat, dalam istilah konstitusi disebut dari kelompok legislative, eksekutif dan masyarakat. Orang-orang yang terlibat dalam proses lahirnya undang-undang dapat juga dikelompokkan menjadi kelompok ahli ('ulama), pemimpin ('umara'), dan tokoh masyarakat (ru'asa'). Kesepakatan ahli, pemimpin, dan tokoh masyarakat ini boleh disamakan dengan keputusan uli al-amr dalam bahasa al-Qur'an. Dengan demikian, mengikuti kesepakatan ahli, pemimpin, dan tokoh masyarakat ini identik dengan mengikuti uli al-amr, kesepakatan yang harus dipatuhi setelah al-Qur'an dan sunnah rasul Muhammad saw, demikian menurut Muhammad 'Abduh.

Seluruh proses pembuatan undang-undang dan peraturan, sesuai dengan UU dan peraturan yang berlaku, tidak selalu bekerja sesuai dengan yang ideal dan apa yang tertulis. Lima tahap pembentukan undang-undang sebagaimana dimaksud dalam undang-undang, mungkin ada di antara tahapan-tahapan yang tidak berjalan sesuai dengan yang ideal dan dinyatakan dalam UU. Mungkin pada tahap perencanaan tidak sesuai dengan aturan UU. Mungkin juga pada

11 Pasal 88 (1) Penyebarluasan dilakukan oleh DPR dan Pemerintah sejak penyusunan Prolegnas, penyusunan Rancangan Undang-Undang, pembahasan Rancangan Undang-Undang, hingga Pengundangan Undang-Undang. (2) Penyebarluasan sebagaimana dimaksud pada ayat (1) dilakukan untuk memberikan informasi dan/atau memperoleh masukan masyarakat serta para pemangku kepentingan.

12 Masyarakat berhak memberikan masukan secara lisan dan/atau tertulis dalam Pembentukan Peraturan Perundang-undangan. (2) Masukan secara lisan dan/atau tertulis sebagaimana dimaksud pada ayat (1) dapat dilakukan melalui: a. rapat dengar pendapat umum; $b$. kunjungan kerja; c. sosialisasi; dan/atau d. seminar, lokakarya, dan/atau diskusi. (3) Masyarakat sebagaimana dimaksud pada ayat (1) adalah orang perseorangan atau kelompok orang yang mempunyai kepentingan atas substansi Rancangan Peraturan Perundang-undangan. (4) Untuk memudahkan masyarakat dalam memberikan masukan secara lisan dan/atau tertulis sebagaimana dimaksud pada ayat (1), setiap Rancangan Peraturan Perundang-undangan harus dapat diakses dengan mudah oleh masyarakat. 
tahap berikutnya, persiapan yang tidak sejalan dengan UU. Juga tidak menutup kemungkinan dalam fase diskusi yang kurang optimal. Demikian juga ada kemungkinan bahwa tidak ideal pada tahap diskusi. Bisa juga pada tahap pengesahan atau penetapan yang tidak sesuai dengan UU. Mungkin juga pada tahap pemberlakuan yang tidak ideal. Akhirnya, mungkin tahap yang tidak ideal adalah pada tahap partisipasi masyarakat.

Namun, dari uraian proses lahirnya undang-undang dalam konstitusi Indonesia, dari perencanaan hingga pengesahan, dapat disimpulkan banyak orang yang terlibat dalam proses kelahiran legislasi. Sebagaimana ditulis sebelumnya, orang-orang yang terlibat para ahli ('âlim, 'ulamâ'), pemimpin ('âmir, 'umarâ'), dan tokoh masyarakat (râis, ru'asâ'). Kesepakatan mereka ini dapat disamakan dengan keputusan uli al-amr dalam bahasa al-Qur'an. Dengan demikian, mengikuti kesepakatan ini identik dengan mengikuti uli al-amr, kesepakatan yang harus dipatuhi setelah al-Qur'an dan sunnah rasul Muhammad SAW.

Untuk membandingkan dengan produk pemikiran hukum Islam lainnya, di luar undang-undang; fikih, fatwa, tafsir (penafsiran), yurisprudensi, dapat dijelaskan bagaimana proses kelahiran masing-masing. ${ }^{13}$ Penjelasan dimulai dari produk hukum Islam berupa fikih. Fikih dari sisi bahasa berarti al-fahmu (pemahaman). Pengertian istilah biasanya fiqh didefinisikan, misalnya, oleh 'Abd al-Wahhb Khallâf, 'kumpulan hukum yang praktis dan rinci, yang berasal dari sumber yang rinci'. ${ }^{14}$ Dalam proses lahirnya fikih ada 3 (tiga) subjek/pihak di dalamnya. Pertama, fâqih (ahli hukum Islam) yang melakukan ijtihad, yang boleh juga disebut mujtahid. Kedua, nash (sumber ajaran Islam) dalam bentuk alQur'an dan sunnah Nabi Muhammad SAW, sebagai sumber pengambilan atau penetapan hukum. Ketiga, fikih (hasil pemahaman / pemikiran dari fâqih pada teks). Dari definisi dan proses ini dapat disimpulkan bahwa fikih adalah hasil / produk pemikiran/pemahaman di bidang hukum Islam sebagai hasil pemahaman terhadap nash al-Qur'an dan sunnah nabi Muhammad saw. Fikih adalah hasil dari pemahaman individu. Intinya, bahwa pemikiran atau fikih adalah hasil dari pemahaman individu, bukan pendapat kolektif (pendapat orang banyak). Adapun jika ada pemahaman yang sama antara satu ahli (mujtahid, fâqih) dengan fâqih lain, atau beberapa ahli (fuqahâ'/ jamak fâqih), hanya bertepatan, bukan dirancang (dengan dirancang)

Fatwa adalah pendapat para ahli tentang masalah tertentu, yang prosedur lahirnya dimulai dengan pertanyaan. Oleh karena itu, dalam prosedur lahirnya fatwa memiliki tiga unsur/pihak. Pertama, mufti, seseorang atau sekelompok ahli yang mengeluarkan pendapat (fatwa). Kedua, mustafti, orang yang bertanya. Ketiga, fatwa, pendapat atau jawaban dari mufti. Secara umum,

\footnotetext{
13 Khoiruddin Nasution, Pengantar Studi Islam, terbit ke-1 Juli 2016 (Jakarta: Pt. RajaGrafindo Persada, 2016), hlm. 60 dst.

14 'Abd al-Wahhâb Khallâf, 'Ilm Us\}âl al-Figh, (Lebanon: Darul Kutub al-'Ilmîyah, 1971), hlm. 11.
} 
seorang mufti adalah orang yang dipercaya oleh masyarakat umum untuk menjawab masalah yang timbul dalam kehidupan masyarakat, yaitu untuk menentukan hukum halal atau haram, boleh atau tidak. ${ }^{15}$ Fatwa dapat dikelompokkan menjadi dua: fatwa individual, dan fatwa kelompok. Di Indonesia fatwa kelompok umumnya lahir dari organisasi keagamaan, seperti Majlis Tarjih dalam Muhammadiyah, Bahtsul Masa'il di Nahdlatul Ulama, dan Majlis Fatwa di MUI. Dengan demikian, fatwa dapat dikelompokkan menjadi dua, yaitu: (1) fatwa yang bersifat individual dan (2) fatwa yang bersifat kelompok, kolektif, hasil pemahaman, ijtihad sejumlah ahli hukum Islam.

Tafsir (Interpretasi) sama dengan fikih, yang juga merupakan hasil pemikiran individu (individu) dari seorang ahli tafsir (mufassir) yang melakukan ijtihad. Mufassir juga mujtahid. Dari definisi ini dapat disimpulkan bahwa tafsir (interpretasi) juga merupakan hasil / produk pemikiran dalam bidang hukum Islam sebagai hasil memahami nash. Dengan demikian, dalam proses lahirnya penafsiran ada 3 (tiga) unsur/pihak utama yang terlibat. Pertama, mufassir (ahli tafsir) yang melakukan ijtihad, sama dengan fikih oleh fâqih. Kedua, nash (sumber ajaran Islam, dalam bentuk al-Qur'an dan sunnah rasul Muhammad SAW.), sebagai sumber pengambilan atau penetapan hukum. Ketiga, tafsir (penafsiran) (hasil pemahaman / pemikiran seorang mufassir dalam memahami nash. Lagi lagi sama dengan fikih, hasil pemahaman bersifat individu, bukan pendapat kolektif (pendapat orang banyak).

Yurisprudensi dalam istilah atau penggunaan yang lebih popular berarti kumpulan keputusan hakim di pengadilan yang dapat digunakan oleh hakim berikutnya sebagai dasar untuk membuat keputusan, terutama dalam kasus hukum belum ditemukan secara tertulis dalam buku-buku hukum. Jadi gagasan utama yang muncul dari yurisprudensi adalah keputusan hakim (qâd\}i). Pada dasarnya proses kelahiran putusan hakim di pengadilan sama dengan proses kelahiran fatwa, yaitu: dimulai dengan orang yang bertanya / mengeluh (masalah orang), kemudian hakim (qâd\}i) memberikan jawaban (keputusan) di pengadilan. Keputusan adalah pendapat atau jawaban dari qâd\}i, dan tentu saja pendapat / jawaban juga didasarkan pada nash (al-Qur'an dan / atau sunnah nabi Muhammad SAW). Perbedaan antara fiqh, tafsir dan fatwa di satu sisi, dengan keputusan hakim di sisi lain, bahwa putusan hakim di pengadilan kadang-kadang kolektif (hakim), misalnya 3 hakim duduk bersama menjadi satu dewan.

Sekali lagi perlu diingatkan bahwa qâd\}î juga seorang mujtahid. Upaya yang mereka lakukan untuk menemukan jawaban disebut ijtihad, sama dengan usaha yang dilakukan oleh fâqih, mufassir, yang juga mufti. Ringkasnya, fâqih, mufassir, mufti, dan qâd\}î sama-sama mujtahid, dan upaya yang mereka lakukan untuk menetapkan atau mengambil dan menegakkan hukum (pendapat) disebut

${ }^{15}$ Al-Nawawi, Adab al-Fatâwâ wa al-Muftî wa al-Mustafrî, edisi ke-2 (Beirût: Dar al-Bashâ'ir wa al-Islâmîyah, 1411/1990), hlm. 75. 
ijtihad. Hasil ijtihad mereka disebut produk pemikiran hukum Islam. Untuk mengingatkan, pemikiran (produk hukum) masing-masing adalah: fâqih (jama'atau pluralnya fuqahâ') melahirkan fikih, mufassir (jama' atau pluralnya mufassirûn/mufassirîn) melahirkan tafsir, mufti melahirkan fatwa, dan qâdi memberikan putusan yang kemudian dihimpun menjadi yurisprudensi.

Kompilasi Hukum Islam (KHI) adalah pendapat orang banyak, sama dengan UUP. Proses lahirnya Kompilasi Hukum Islam (KHI) prinsipnya juga sama dengan proses lahirnya UU. Tahapan prosesnya adalah; 1. perencanaan, 2. persiapan, 3. pembahasan, 4. penetapan, dan 5. pemberlakuan. Dalam proses lahirnya KHI hanya satu proses yang tidak dilakukan ketika dibandingkan dengan proses lahirnya UU, yaitu tahap penetapan. Ini juga alasan mengapa KHI tidak menjadi undang-undang. Dengan proses yang dilakukan dalam kelahiran KHI, terbukti bahwa keterlibatan banyak ahli dan ilmuwan sama dengan proses kelahiran UU. Begitu pula dengan keterlibatan banyak pemimpin dalam memproduksi KHI sama seperti dalam UU. Dengan demikian KHI juga merupakan hasil pemikiran banyak orang, banyak ahli, banyak ilmuwan, banyak pemimpin, hanya proses kelahirannya kurang satu tahap jika dibandingkan dengan UU. Jadi tidak berlebihan untuk mengatakan kekuatan hukum KHI sama dengan UU dari sisi jumlah orang yang terlibat; ahli, pemimpin, dan tokoh masyarakat.

Jadi ketika produk pemikiran hukum Islam dikelompokkan, maka muncul dua kelompok besar. Pertama, produk pemikiran hukum Islam yang bersifat individual. Kedua, produk pemikiran yang bersifat kolektif. Produk pemikiran hukum Islam yang bersifat individual adalah fikih, fatwa, tafsir (interpretasi), dan yurisprudensi. Fatwa dan yurisprudensi bersifat individual, karena meskipun ada pemikiran kolektif, jumlah ahli yang terlibat tetap sangat terbatas jika dibandingkan dengan produk pemikiran hukum Islam kolektif berupa undang-undang dan KHI. Dengan demikian, ada dua produk pemikiran Hukum Islam kolektif, yaitu UU dan KHI.

\section{Konsep Ijmâ' Muhammad 'Abduh dan Relevansinya dengan UU Perkawinan Indonesia}

Untuk memahami konsep Ijmâ' Muhammad 'Abduh lebih lengkap, perlu diketahui tentang kehidupan 'Abduh. 'Abduh lahir pada tahun 1266 H / 1849 di sebuah desa di Provinsi Gharbiyah, Mesir. Setelah pindah dari desa asli Mahallat al-Nashr, wilayah Shubrakhit, Provinsi Buhayrah, ayahnya, 'Abduh bin Hasan Khairullah telah membangun sebuah rumah untuk keluarganya di desa baru. Ibu 'Abduh bernama Junaynah, adalah seorang janda yang berasal dari sebuah desa dekat Tanta, Provinsi Gharbiyah. ${ }^{16}$ Kelahiran 'Abduh bertepatan dengan waktu ketika masyarakat tidak mendapatkan keadilan dari pemerintah. Saat itu Mesir

${ }^{16}$ Muhammad Y. Faruqi, “The Development of Ijma ': The Practices of the Khulafa' alRashidun and the Views of the Classical Fuqaha', The American Journal of Islamic Sciences 9:2 (Summer 1992), pp. 173-187. 
dipimpin oleh Muhammad Ali Pasha. Ayah Abduh adalah di antara banyak orang yang tidak setuju dan menentang kebijakan tirani Muhammad Ali Pasha. Salah satu kebijakan tirani dimaksud adalah pajak tinggi yang harus dibayar rakyat. Akibatnya, bapak 'Abduh diusir oleh pemerintah selama 15 tahun. Setelah selesai tirani, ayahnya kembali ke Mahlat Nashr, tempat di mana 'Abduh tumbuh, berkembang dan menghabiskan sebagian besar masa kecilnya. Awal pendidikannya, usia 10 'Abduh belajar membaca dan menulis dari ayahnya. Kemudian 'Abduh dikirim untuk belajar al-Qur'an di masjid Ahmadiyah di Tanta. Akhirnya, mendapat gelar al-Qari al-Hafidz. 'Abduh mampu menghafal seluruh al-Qur'an dalam jangka waktu 2 (dua) tahun, sesuatu yang tidak biasa dilakukan oleh banyak orang.

'Abduh berhenti sekolah karena metode pembelajaran yang menurutnya tidak cocok. Akhir dari kekecewaannya 'Abduh menikah. Untungnya, Abduh bertemu Jamaluddin al-Afghani, yang mengubah takdirnya karena dia diajak untuk pergi bersama ke Paris Prancis dan menjadi muridnya dari tahun 1871 hingga 1879. Bersama dengan al-Afghani mereka mendirikan Jurnal "al-Urwah al-Wusqa" di Paris, sebagai media untuk melakukan gerakan politik. Sejak ia diangkat sebagai Mufti Besar Mesir pada 3 Juni 1899, dan menjadi anggota Badan Legislatif pada 22 Juni 1899, 'Abduh melakukan banyak upaya reformasi di Mesir. Di antara reformasinya adalah pembaruan pengadilan dan mengubah kurikulum sekolah. Hakim dilengkapi dengan pengetahuan umum. Kurikulum diubah dari kurikulum yang hanya mempelajari pengetahuan agama ditambah dengan pengetahuan umum. Demikian juga, mengubah metode pembelajaran konvensional menjadi lebih baru. ${ }^{17}$

Mematuhi undang-undang bagi 'Abduh sama statusnya dengan mematuhi al-Qur'an dan Sunnah Nabi Muhammad. Sebab menaati undangundang yang ditetapkan oleh wakil rakyat (parlemen) merupakan bentuk kepatuhan kepada pemerintah (uli al-amr). Kewajiban patuh kepada pemerintah dalam bentuk undang-undang adalah realisasi perintah untuk mematuhi Allah, mematuhi rasul dan mematuhi pemerintah (uli al-amr), sebagaimana disebutkan dalam al-Nisa' (4): 59 dan al-Nisa' (4): 83. Di sisi lain, Undang-undang sebagai bentuk keputusan wakil-wakil rakyat adalah perwujudan kesepakatan seluruh rakyat. Rakyat secara keseluruhan diwakili oleh dewan perkawilan rakyat, karena untuk mengumpulkan semua orang, saat ini, adalah sesuatu yang tidak mungkin. Sebagai solusinya, sistem representasi adalah salah satu cara yang bisa diambil. Jadi keputusan wakil-wakil ini diposisikan sebagai keputusan seluruh rakyat. Konsekuensinya, keputusan ini harus dipatuhi. Persetujuan dari perwakilan rakyat ini juga untuk saat ini merupakan bentuk ijmâ', yang merupakan sumber hukum Islam ketiga setelah al-Qur'an dan sunnah Nabi Muhammad saw.

17 Jamal Muhammed Ahmed, The Intellectul Origins of Egyptian Nationalism (London: Oxford University Press, 1960), hlm. 40. 
Konsep ijmâ' 'Abduh berbeda dari konsep pemikir pada umumnya. Pemikir pada umumnya menuntut kesepakatan seluruh umat Islam (muslim) sebagai kesepakatan yang harus dipatuhi. Menurut 'Abduh, persetujuan seluruh umat dari seluruh dunia, untuk saat ini, sudah tidak relevan dengan tiga alasan utama. Pertama, jumlah umat Islam begitu besar, tidak mungkin untuk dikumpulkan, atau sangat sulit untuk dikumpulkan. Kedua, konteks kebutuhan dan tuntutan yang berbeda antara satu negara dengan negara lain. Demikian juga, kriteria dan tuntutan untuk kesejahteraan satu bangsa dengan yang lain, bahkan antara satu kota dengan kota lain yang berbeda. Jadi pertimbangan kesejahteraan bervariasi antara satu Negara dengan Negara lain sesuai dengan tuntutan tempat, keadaan, dan lingkungan yang berbeda. Perbedaan ini menjadi pertimbangan. ${ }^{18}$ Ketiga dan merupakan kelanjutan dari alasan kedua, tujuan pembentukan dan penegakan UU yang merupakan ketentuan negara adalah untuk menegakkan dan mewujudkan kesejahteraan dan kemakmuran rakyat. Kesejahteraan dan kemakmuran rakyat juga sangat tergantung pada konteks negara. Oleh karena itu, kesepakatan warga di satu negara, yang diwakili oleh orang-orang terpilih, adalah jalan keluarnya, demikian 'Abduh.

Kewajiban untuk mematuhi undang-undang sebagai bentuk kesepakatan wakil rakyat adalah perwujudan dari kewajiban patuh kepada pemerintah (uli al$a m r$ ), yang berarti bersifat formal dan legal. Dasar kewajiban mematuhi undangundang adalah kewajiban patuh kepada pemerintah, sebagaimana tercantum dalam surat al-Nisa' (4): 59 dan al-Nisa' (4): 83. Kewajiban patuh kepada pemerintah, untuk konteks saat ini, menurut 'Abduh, adalah pemerintahan dalam satu negara, bukan pemerintahan dalam konteks negara Islam di seluruh dunia Muslim.

Untuk lengkapnya, dua ayat al-Qur'an dimaksud adalah berikut, al-Nisa' (4): 59,

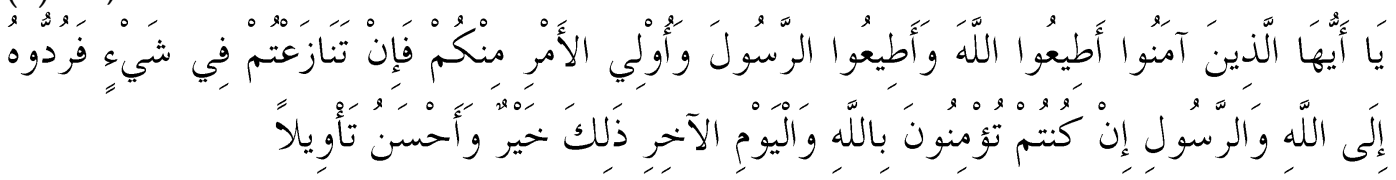

"Hai orang-orang yang beriman! Taatilah Allah dan taatilah Rasul (Dia), dan ulil amri di antara kamu. Kemudian jika Anda tidak setuju tentang sesuatu, maka kembalikan kepada Allah (Al-Qur'an) dan Nabi (sunnah), jika Anda benar-benar percaya kepada Allah dan hari setelah itu. Itu lebih penting (untuk Anda) dan lebih baik sebagai reult".

Al-Nisa' (4): 83,

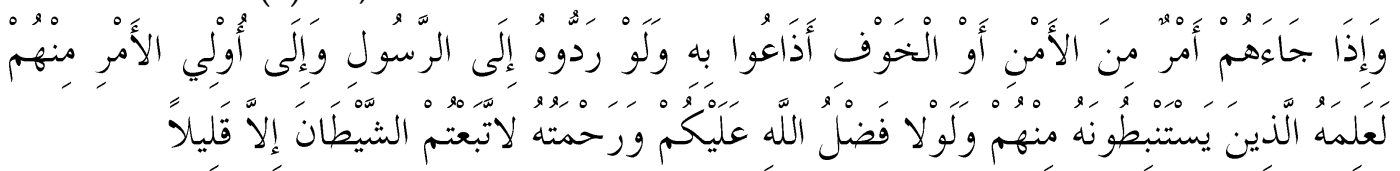

"Dan ketika datang kepada mereka berita tentang keamanan atau ketakutan, mereka kemudian menyiarkannya. Dan jika mereka memberikannya kepada Rasul dan ulil amri

${ }^{18}$ Muhammad Rasyid Rid\}a, Tafsîr al-Manâr (Kairo: Dar al-Manar, 1373), V:208-209. 
di antara mereka, tentunya mereka yang ingin mengetahui kebenaran (akan dapat) mengetahuinya dari mereka (Rasul dan ulil amri). Jika bukan karena karunia dan rahmat Allah untuk Anda, tentunya Anda akan mengikuti syaitan, kecuali untuk sebagian kecil (di antara Anda)".

Arti kata uli al-amr dalam al-Nisa' (4): 59 dan 83, menurut 'Abduh terdiri dari dua kelompok besar, yaitu para ahli dalam berbagai bidang keilmuan ('âlim kata tunggal, 'ulama' plural), dan pemimpin terkenal di masyarakat (râ'is tunggal, ruasa'/ ru'ûs al-nas jamak), baik di lingkungan kesukuan, di kota, tingkat provinsi, dan seterusnya hingga tingkat nasional. Pemahaman seperti itu sesuai dengan arti kata uli al-amr, di mana kata itu dalam bentuk jamak (plural), yang berarti sejumlah orang terkenal dalam komunitas. ${ }^{19}$ Untuk mendukung teori tersebut, 'Abduh memberikan fakta-fakta historis tentang umat Islam, terutama pada masa khulafa' al-râsyidîn, lebih khusus dua khalifah pertama. Pada saat itu, kata uli al-amr digunakan untuk merujuk orang-orang yang menjadi tokoh masyarakat (pemimpin ru'asa') dan ahli ('ulamâ', ilmuwan) di berbagai bidang ilmiah ('ulamâ'). ${ }^{20}$

Dasar yang membuat para ilmuwan dan pemimpin terkenal di masyarakat adalah karena kemampuan mereka memecahkan masalah yang timbul di lingkungan mereka. Dengan demikian, status mereka sebagai perwakilan masyarakat didasarkan pada kecakapan dan kepercayaan masyarakat terhadap kemampuan mereka di berbagai bidang kehidupan sosial, baik kemampuan yang terkait dengan sains (sebagai ilmuwan) dan kemampuan memimpin (sebagai seorang pemimpin).

Di tempat lain, 'Abduh mengatakan, kata uli al-amr sebenarnya adalah kata ganti dari para ahli dalam memecahkan masalah yang dihadapi umat. Jadi uli al-amr dengan sendirinya adalah orang-orang yang diyakini mampu memberikan kesejahteraan kepada ummah. Untuk mendukung pendapat ini, 'Abduh kembali merekam realitas historis umat Islam yang terjadi selama masa Nabi Muhammad dan Khulafa' al-râsyidîn, terutama dua khalifah pertama, Abu Bakar dan Umar bin Khattab. 'Abduh mencatat, pada masa Rasulullah, ada sejumlah orang di Madinah yang kepada mereka orang-orang di Madinah berkonsultasi dalam memecahkan masalah yang mereka hadapi; di bidang politik, administrasi, peradilan, dan bidang lainnya.

Upaya mendapatkan wakil terbaik dan berkualitas sesuai dengan kriteria di atas, menurut 'Abduh, bisa dilakukan dengan mengadakan pemilihan umum, yang bisa dilakukan mulai dari tingkat kota, provinsi, hingga tingkat nasional. Di sisi lain, masih dalam rangka untuk mendapatkan kandidat yang benar-benar berkualitas, pemilih harus benar-benar diberi kebebasan. Sejalan dengan upaya

${ }^{19}$ Ahmad Hasan, The Doctrine of ijma' in Islam (Pakistan: Islamic Research Institute, 1976), khususnya hlm. 226-258.

${ }^{20}$ Muhammad Y. Faruqi, “The Development of Ijma': The Practices of the Khulafa' alRashidun and the Views of the Classical Fuqaha', The American Journal of Islamic Sciences 9:2 (Summer 1992), pp. 173-187. 
ini, Faruki memiliki ide yang sama dengan 'Abduh, bahwa untuk mendapatkan perwakilan yang benar-benar kompeten dan dapat dipercaya, adalah melalui pemilihan umum (pemilihan umum). ${ }^{21}$

Dengan ringkas dapat ditulis tiga dasar pokok yang digunakan 'Abduh mewajibkan umat patuh kepada undang-undang. Pertama, al-Qur'an memerintahkan patuh kepada Allah, rasul dan pemerintah (uli al-amr). Kedua, ketetapan yang dibuat pemerintah merupakan salah satu unsur pemerintah yang wajib dipatuhi. Ketiga, undang-undang merupakan ijmâ' yang wajib dipatuhi, sebab ijmâ' merupakan sumber ketiga setelah al-Qur'an dan sunnah nabi Muhammad saw. Di samping itu dan sebagai dasar penguat, undang-undang merupakan hasil pemikiran hukum Islam yang paling otoritatif dan konfrehensif dibandingkan dengan fikih, fatwa, tafsir dan yurisprudensi.

\section{Mematuhi Undang-Undang Perkawinan}

Berdasarkan konsep 'Abduh tersebut di atas dapat disimpulkan bahwa mematuhi UU Perkawinan Nomor 1 Tahun 1974 tentang Perkawinan, dan peraturan Perundang-undangan lainnya, termasuk Kompilasi Hukum Islam (KHI) adalah wajib bagi warga negara Indonesia. Undang-undang lainnya adalah; UU No. 7 tahun 1989 tentang Pengadilan Agama, UU No. 3 tahun 2006 tentang Perubahan atas Undang-Undang Nomor 7 Tahun 1989 tentang Pengadilan Agama, Peraturan Pemerintah (PP) No. 10 tahun 1983 tentang Perkawinan dan Izin Perceraian untuk Pegawai Negeri Sipil (PNS), Peraturan Pemerintah (PP) No. 45 tahun 1990 tentang Amandemen terhadap PP No. 10 tahun 1983 tentang Perkawinan dan Izin Perceraian untuk Pegawai Negeri Sipil (PNS) dan Kompilasi Hukum Islam 1991.

Kewajiban untuk mematuhi undang-undang dan berbagai peraturan ini sebagai realisasi kewajiban patuh kepada pemerintah Indonesia (uli al-amr), sebagaimana diperintahkan dalam al-Nisa' (4): 59 dan 83. Selain itu, undangundang sebagai produk pemikiran sejumlah ahli di berbagai bidang keilmuan, dan para ahli dalam memecahkan berbagai masalah masyarakat, memiliki kekuatan hukum yang lebih komprehensif dan kuat (otoritatif dan objective) dari produk berupa fikih, fatwa dan yurisprudensi yang bersifat individu. Sebab yurisprudensi dan fatwa pada prinsipnya hanya produk hukum Islam yang bersifat individual (individual). Sementara undang-undang adalah hasil pemikiran banyak ahli (kolektif), dan 'Abduh memposisikan undang-undang sebagai ijmâ', sumber ketiga hukum Islam setelah al-Qur'an dan sunnah Nabi Muhammad. Sehingga mematuhi undang-undang sama dengan mematuhi perintah patuh kepada pemerintah dan menerapkan ijmấ sebagai sumber hukum Islam ketiga setelah al-Qur'an dan Sunnah Nabi Muhammad. Dengan

${ }^{21}$ Muhammad Nazeer Ka Ka Khel, “The Conceptual and Institutional Development of Shura in Early Islam," Islamic Studies 19 (1980), pp. 271-282. 
singkat, ada tiga alasan dasar mengapa Undan-Undang Perkawinan wajib dipatuhi menurut 'Abduh. Pertama, mematuhi undang-undang adalah realisasi dari perintah patuh kepada pemerintah (uli al-amr). Kedua, menaati undangundang merupakan realisasi dari patuh pada hukum hasil ijmâ', sumber ajaran Islam setelah al-Qur'an dan sunnah Nabi Muhammad saw. Ketiga, undangundang merupakan hasil pemikiran sejumlah ahli; ahli berbagai bidang keilmuan dan ahli dalam menyelesaikan masalah-masalah masyarakat.

Dari proses penetapan undang-undang dalam konstitusi Indonesia, dapat disimpulkan betapa banyak ahli yang terlibat, ahli dalam berbagai aspek kehidupan di masyarakat. Sehingga keterlibatan sejumlah ahli ini ketika dikaitkan dengan substansi pendapat 'Abduh yang mewajibkan umat Islam mematuhinya, bahwa dalam proses pembuatan undang-undang di Indonesia juga ada banyak ahli yang terlibat. Dengan demikian tidak berlebihan untuk menyatakan bahwa undang-undang yang dibuat berdasarkan konstitusi Indonesia sejalan dengan pemikiran 'Abduh.

Memang, peraturan perundang-undang perkawinan Indonesia tidak hanya dalam bentuk undang-undang, tetapi ada juga Peraturan Pemerintah (PP) dan Kompilasi Hukum Islam (KHI). Tetapi perlu dicatat bahwa kedua aturan ini pada prinsipnya memuat peraturan yang sejalan dan mendukung isi undangundang. Peraturan pemerintah adalah implementasi dan deskripsi undangundang, sehingga substansinya harus sesuai dengan undang-undang. Sedangkan KHI juga hasil pemikiran banyak orang, sama dengan proses lahirnya UU, hanya tahap penetapan oleh badan legislative yang tidak ditemukan dalam proses lahirnya KHI. Jadi tidak berlebihan untuk mengatakan kekuatan undang-undang sama dengan KHI. Dengan demikian berdasarkan konsep 'Abduh, umat Islam wajib mematuhi aturan yang tertulis dalam UU dan berbagai peraturan perkawinan. Di antara aturan yang tertulis dalam undang-undang perkawinan Indonesia yang wajib dipatuhi adalah sebagai berikut;

Pertama, prinsip perkawinan adalah monogami, sebagaimana dinyatakan dalam UU No. 1 tahun 1974 tentang Perkawinan, Pasal 3 ayat (1), pada prinsipnya dalam perkawinan seorang laki-laki hanya boleh memiliki istri, seorang wanita hanya boleh memiliki suami. Memang ada kemungkinan poligami untuk seorang suami, tetapi hanya dalam kondisi tertentu dan dengan persyaratan tertentu, sebagaimana dinyatakan dalam Pasal 3 ayat (2) UU No. 1 tahun 1974 tentang Perkawinan. Pengadilan dapat memberikan izin suami untuk memiliki lebih dari satu istri jika diinginkan oleh pihak yang bersangkutan. Pasal 4 ayat (1), Jika seorang suami memiliki lebih dari satu istri sebagaimana disebutkan dalam Pasal 3 ayat (2) Undang-undang ini, ia wajib mengajukan permohonan ke Pengadilan di daerah tempat tinggalnya. Pasal 4 ayat (2) Pengadilan sebagaimana dimaksud pada ayat (1) pasal ini hanya memberikan izin kepada suami yang akan memiliki lebih dari satu istri jika (1) istri tidak dapat melaksanakan kewajibannya sebagai istri; (2) 
istri mendapat cacat atau penyakit yang tidak dapat disembuhkan, (3) istri tidak dapat melahirkan anak.

Selain itu, suami yang akan berpoligami juga harus dapat memenuhi persyaratan tertentu, sebagaimana dinyatakan dalam pasal 5 ayat (1) UU. Untuk dapat mengajukan permohonan ke Pengadilan sebagaimana dimaksud dalam Pasal 4 ayat (1) harus dipenuhi sebagai berikut: a. Ada kesepakatan dari istri / istri; b.ada kepastian bahwa suami dapat menjamin kebutuhan hidup istri dan anak-anak mereka; c. Ada jaminan bahwa suami akan berlaku adil terhadap istri dan anak-anak mereka. Aturan yang sama disebutkan dalam artikel KHI 55 hingga 59.

Kedua, perlunya persetujuan kedua calon pengantin, seperti yang disebutkan dalam Undang-undang Nomor 1 Tahun 1974 tentang Perkawinan. Pasal 6, 'pernikahan harus didasarkan pada kesepakatan dua pengantin perempuan'. Aturan yang sama dinyatakan dalam KHI pasal 16.

Ketiga, aturan usia untuk laki-laki dan perempuan, sebagaimana disebutkan dalam UU No. 1 tahun 1974 tentang Perkawinan. Pasal 7 ayat (1), perkawinan hanya diizinkan jika laki-laki telah mencapai usia 19 (sembilan belas) tahun dan wanita telah mencapai usia 16 (enam belas) tahun. Aturan yang sama dinyatakan dalam artikel KHI 15.

Keempat, perceraian hanya dapat dilakukan di depan sidang pengadilan, sebagaimana tercantum dalam UU No. 1 tahun 1974 tentang Perkawinan. Pasal 39 ayat (1), perceraian hanya dapat dilakukan di depan sidang pengadilan setelah pengadilan mencoba dan tidak berhasil mendamaikan kedua pihak. Aturan yang sama dinyatakan dalam artikel KHI 115.

Konten yang sama juga disebutkan dalam beberapa undang-undang dan peraturan, seperti Peraturan Pemerintah No. 10 tahun 1983 Tentang Izin Pernikahan dan Perceraian bagi Pegawai Negeri Sipil, dan peraturan perundangundangan Indonesia lainnya, seperti Kompilasi Hukum Islam Indonesia. Penerapan Kompilasi Hukum Islam (KHI) didasarkan pada Instruksi Presiden No. 1 tahun 1990.

Kelima, hak waris untuk anak laki-laki dan perempuan, termasuk untuk anak-anak dari anak yang meninggal lebih dulu. Bahwa bagian anak laki-laki sama dengan bagian perempuan, sebagaimana dinyatakan dalam Kompilasi Hukum Islam. Dalam Kompilasi Hukum Islam pasal 183, "Para ahli waris dapat menyetujui perdamaian dalam distribusi warisan, setelah masing-masing menyadari bagiannya".

Keenam, kemungkinan adanya Waris Pengganti, seperti yang disebutkan dalam Kompilasi Hukum Islam. Dalam KHI pasal 185 ayat (1), "Ahli waris yang meninggal lebih awal dari wali, posisi mereka dapat digantikan oleh anak-anak mereka, kecuali mereka yang ada dalam Pasal 173". KHI pasal 173, bahwa ahli waris tidak berhak atas warisan karena pembunuhan ahli waris atau tidak berhak atas warisan karena melakukan fitnah yang mengakibatkan ahli waris dijatuhi hukuman penjara 5 tahun atau hukuman yang lebih berat. 
Demikian juga, aturan pendaftaran perkawinan dimaksudkan sebagai sarana untuk memastikan bahwa perkawinan yang akan dilakukan telah memenuhi ketentuan yang ditetapkan dalam undang-undang Indonesia. Aturan tersebut dinyatakan dalam UU No. 1 tahun 1974 tentang Perkawinan, pasal 2, dan peraturan yang sama dinyatakan dalam artikel KHI 5.

Relevansi pandangan 'Abduh dalam konteks Indonesia, bahwa mayoritas umat Islam Indonesia masih mempertentangkan fikih, fatwa, tafsir dan yurisprudensi (putusan hakim) di satu sisi, dengan undang-undang di sisi lain. Fikih, fatwa, tafsir dan yurisprudensi memiliki posisi dan otoritas yang sama, seolah menjalankan al-Qur'an dan Sunnah Nabi Muhammad, dengan menyebut hukum Islam. Sementara undang-undang merupakan produk negara yang tidak wajib dipatuhi. Akibatnya, legalitas perkawinan hanya didasarkan fikih, fatwa dan tafsir. Sementara Undang-Undang Perkawinan dan peraturan lainnya hanya dalam rangka mematuhi aturan Negara, bukan penentu sah atau tidaknya perkawinan. Dengan meminjam Teori Tindakan Sosial Max Weber, perilaku ini masih dalam posisi Tindakan Emosional dan / atau Tradisional, belum mencapai tindakan rasional obyektif. Padahal dengan mempertimbangkan proses lahirnya undang-undang di satu sisi, dengan proses lahirnya produk fikih, fatwa dan tafsir, di sisi lain, tentu saja undang-undang lebih otoritatif dan komprehensif. Sebab dalam proses lahirnya undang-undang melibatkan banyak orang dan banyak ahli. Para ahli yang dilibatkan juga dari berbagai keilmuan dan keahlian. Demikian juga para pemimpin yang terlibat dalam proses lahirnya undangundang juga berasal dari berbagai lapisan, berbagai konteks, dan berbagai budaya.

\section{Kesimpulan}

Berdasarkan pembahasan di atas dapat disimpulkan bahwa dasar yang digunakan Muhammad 'Abduh untuk mengatakan mematuhi Undang-Undang Perkawinan (UUP) sama dengan kewajiban mematuhi/menaati al-Qur'an dan Sunah rasul Muhammad SAW, ada tiga. Pertama, mematuhi UUP yang ditetapkan wakil-wakil rakyat (DPR, parlemen) adalah bentuk kepatuhan terhadap pemerintah (uli al-amr). Kewajiban patuh kepada pemerintah dalam bentuk patuh pada UUP merupakan realisasi dari perintah mematuhi Allah, mematuhi rasul dan mematuhi pemerintah (uli al-amr), sebagaimana diwajibkan dalam al-Nisa' (4): 59 dan 83. Kedua, wujud persetujuan rakyat dan/atau perwakilan rakyat untuk saat ini adalah ijmâ', sumber ketiga hukum Islam setelah al-Qur'an dan sunnah rasul Muhammad SAW. Ketiga, dibandingkan dengan fikih, fatwa, tafsir, dan yurisprudensi, sebagai produk pemikiran hukum Islam, UUP menempati posisi paling otoritatif dan konprehensif, sebab UUP merupakan hasil pemikiran banyak ahli dari berbagai keilmuan dan keahlian. 
ADHKI: Journal of Islamic Family Law

\section{Daftar Pustaka}

'Abd al-Wahhâb Khallâf, 'Ilm Us\}ûl al-Fiqh. Lebanon: Darul Kutub al-'Ilmîyah, 1971.

Ahmad Hasan, The Doctrine of ijma' in Islam. Pakistan: Islamic Research Institute, 1976.

Al-Nawawi, Adab al-Fatâwâ wa al-Muftî wa al-Mustafrî, edisi ke-2. Beirût: Dar alBashâ'ir wa al-Islâmîyah, 1411/1990.

George Ritzerr, Teori Sosiologi: dari Sosiologi Klasik sampai Perkembangan Terakhir Postmodern, edisi ke-18, terj. Saut Pasaribu dkk.. Yogyakarta: Pustaka Pelajar, 2014.

Jamal Muhammed Ahmed, The Intellectual Origins of Egyptian Nationalism. London: Oxford University Press, 1960.

Khoiruddin Nasution, Pengantar Studi Islam, terbit ke-1 Juli 2016. Jakarta: Pt. RajaGrafindo Persada, 2016.

Muhammad Nazeer $\mathrm{Ka} \mathrm{Ka}$ Khel, "The Conceptual and Institutional Development of Shura in Early Islam," Islamic Studies 19 (1980), pp. 271282.

Muhammad Rasyid Rid\}a, Tafsîr al-Manâr. Kairo: Dar al-Manar, 1373.

Muhammad Y. Faruqi, “The Development of Ijma': The Practices of the Khulafa' al-Rashidun and the Views of the Classical Fuqaha', The American Journal of Islamic Sciences 9:2 (Summer 1992), pp. 173-187.

Undang-Undang No. 12 tahun 2011 tentang Pembentuak Peraturan Perundangundangan.

Undang-Undang No. 10 tahun 2004 tentang Pembentukan Peraturan Perundangundangan. 